\title{
Climate variability of the tropical Andes since the late Pleistocene
}

\author{
A. Bräuning \\ Institute for Geography, University of Erlangen-Nuremberg, Germany \\ Received: 10 May 2009 - Revised: 12 June 2009 - Accepted: 17 June 2009 - Published: 13 October 2009
}

\begin{abstract}
Available proxy records witnessing palaeoclimate of the tropical Andes are comparably scarce. Major implications of palaeoclimate development in the humid and arid parts of the Andes are briefly summarized. The long-term behaviour of ENSO has general significance for the climatic history of the Andes due to its impact on regional circulation patterns and precipitation regimes, therefore ENSO history derived from non-Andean palaeo-records is highlighted. Methodological constraints of the chronological precision and the palaeoclimatic interpretation of records derived from different natural archives, such as glacier sediments and ice cores, lake sediments and palaeo-wetlands, pollen profiles and tree rings are addressed and complementary results concerning former climatic conditions are discussed in terms of possible implications of former atmospheric circulation patterns and main climatic forcing factors. During the last years, increasing tree-ring information is getting available from the tropical Andes, providing high-resolution climate-sensitive records covering the past centuries for the study of climate variability.
\end{abstract}

\section{Introduction}

The climate of the tropical Andes is controlled by a complex interaction between various atmospheric circulation patterns. Of great importance are the position of the Intertropical Convergence Zone (ITCZ) during austral summer (DecemberMarch) and the intensity of the so called "South American Summer Monsoon" (SASM) and the South American LowLevel Jet, transporting moisture from the Atlantic Ocean along the eastern declivity of the Andes. The position of the Bolivian High and the Gran Chaco Low modulate interan-

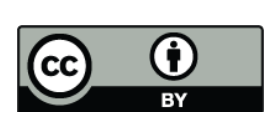

Correspondence to: A. Bräuning (abraeuning@geographie.unierlangen.de) nual variations of summer rainfall on the Altiplano, which is generally controlled by upper tropospheric easterlies and by the frequency and intensity of the El Niño-Southern Oscillation (ENSO) phenomenon (Garreaud et al., 2003, 2008; Zech et al., 2008). The latter is modulated by the thermal gradient of sea surface temperatures (SST) between the eastern and western tropical Pacific and by the strength and position of the trade winds originating from the South Pacific Subtropical High (SPSH). If the SPSH shifts further equator wards or loses strength, the polar front in the southeastern Pacific might shift further north, leading to winter precipitation in the southern part of the tropical Andes (van Geel et al., 2000).

However, it is not clear how the major climatic forcing factors interacted in space, time and intensity during different climatic epochs which are recorded in various natural archives. One aim of this paper is to highlight major results of palaeoclimatic evidence available for the humid and arid parts of the tropical Andes which are delineated here roughly between $10^{\circ} \mathrm{N}$ and $25^{\circ} \mathrm{S}$. This part of the Andes is dominated by moisture bringing winds originating from the Atlantic Ocean (the South American summer monsoon, SASM) leading to precipitation throughout the year or predominantly during austral summer (mainly concentrated during December to March). The very sensitive climatological transition zone to the westerly wind belt is marked by the "South American Dry Diagonal" which crosses the Andes between 18 and $29^{\circ} \mathrm{S}$ (centred between 25-26 S; Ammann et al., 2001) from SE to NW. The subtropical part of the Andes that are dominated by the westerly winds as major source of moisture will not be regarded here.

The major focus of this paper is to point at specific limitations and caveats of climate reconstructions derived from various natural archives that are available in different climatic and topographic environments in the humid and arid parts of the tropical Andes. The first chapter deals with the history of the ENSO circulation system, despite some of the

Published by Copernicus Publications on behalf of the European Geosciences Union. 
archives used for this reconstruction are not of Andean origin. However, since the ENSO phenomenon is also of vital importance for climate variability of the Andes, a brief overview of ENSO variability since the late Pleistocene is given. Then, various archives are discussed separately and palaeoclimatic implications for the humid and the arid tropical Andes are presented. Special emphasis will be laid on the scope of dendroclimatology in the humid Andes. In the final discussion, specific methodological problems of the various climate archives shall be addressed and demands and challenges for future palaeoclimatic research in the tropical Andes will be outlined.

\section{ENSO variability since the late Pleistocene}

ENSO is a coupled ocean-atmospheric circulation phenomenon. Hence, terrestrial as well as marine archives have to be consulted to decipher its history. Concerning ENSO variability during the Pleistocene cold stages of the last $450 \mathrm{kaBP}$, fluctuations in the isotope content of $\delta^{18} \mathrm{O}$ and $\mathrm{Mg} / \mathrm{Ca}$ relations in fossil planktonic foraminifera indicate that the zonal temperature gradient between the eastern and western equatorial Pacific Ocean was about $1^{\circ} \mathrm{C}$ larger than today. This points to enhanced trade winds and more $\mathrm{La}$ Niña-like conditions during glacial periods, whereas during interglacial periods, the SST gradient was about $1^{\circ} \mathrm{C}$ smaller than today (Lea et al., 2000). From the variance of $\delta^{18} \mathrm{O}$ isotope variations of fossil in comparison to modern corals it can be inferred that the strength of ENSO events during the last $130 \mathrm{ka}$ was smaller than at present, except during the last interglacial period at around 118-128 ka (Tudhope et al., 2001). Reasons for this might be found in lower sea-surface temperatures, strengthened trade winds and variations in the perihel position of the sun related to the precessional cycle of the earth (Tudhope et al., 2001). Estimates for SST lowering during the Last Glacial Maximum (ca. 23-19 ka BP) in the eastern equatorial Pacific vary between $1.2^{\circ} \mathrm{C}$ (Koutavas et al., 2002) and $2.6 \pm 0.8^{\circ} \mathrm{C}$. During the early Holocene, eastern Pacific SSTs were ca. $1^{\circ} \mathrm{C}$ higher than today (Lea et al., 2000).

Contrasting views exist about the history of ENSO in the mid-Holocene. Faunal warm-water indicators off the northern Peruvian coast seem to indicate stable warm water conditions and an onset of ENSO events not before $5 \mathrm{kaBP}$ (Sandweiss et al., 1996). Other studies, however, found evidence for cooler eastern Pacific SSTs (Otto-Bliesner, 1999) and an enhanced SST gradient between the east and west equatorial Pacific (Koutavas et al., 2002). These findings suggest that the faunal records along the Peruvian coast represent only local conditions in narrow coastal embayments. Analyses of flood sediments along the coast of northern Peru give evidence that ENSO was present throughout the Holocene period but was restricted to a region north of $11^{\circ} \mathrm{S}$ (Wells, 1990). This view is corroborated by experiments with coupled ocean-atmosphere climate models that indicate that ENSO intensity was lowered and shifted to a $\mathrm{La}$ Niña-like state during the early and middle Holocene (OttoBliesner, 1999). Due to increased solar radiation input on the Northern Hemisphere during boreal summer, the Asian monsoon system was enhanced. This led to stronger trade winds and increased upwelling of cold water in the eastern Pacific with warmer SSTs in the western Pacific (Liu et al., 2000; Clement et al., 2000).

Although the preservation of older flood deposits is uncertain, the recurrence interval of strong El Niño events seems to have accelerated during the past 7000 years. A sediment core from Laguna Pallcacocha in southwestern Ecuador $\left(2^{\circ} 46^{\prime} \mathrm{S} 79^{\circ} 14^{\prime} \mathrm{W} ; 4200 \mathrm{~m}\right.$; Fig. 3a) mirrors the input of clastic laminated sediments into a cirque lake driven by ENSOrelated flood events. The time series characteristics of deposited inorganic and organic-rich laminae revealed a period of weak ENSO in the Late Glacial and early Holocene (15-7 ka BP) with a periodicity of more than 15 years (Rodbell et al., 1999). After ca. 6-5 ka BP, the magnitude and frequency of the ENSO signal is similar as today, with a periodicity of 2-8.5 years (Otto-Bliesner, 1999; Rodbell et al., 1999). However, several ENSO activity peaks were determined around $4800 \mathrm{BP}, 2500 \mathrm{BP}$ and 1200 years ago, when Holocene ENSO activity culminated (Moy et al., 2002; Fig. 2c). Since then, the intensity of ENSO in southwestern Ecuador is generally decreasing. During the upper Medieval period (around AD 800-1250), terrestrial archives in Ecuador as well as marine records off the Peruvian coast indicate very dry conditions (Moy et al., 2002; Rein et al., 2004). They are contemporaneous with drought episodes in other regions around the Indo-Pacific Basin and thus highlight the role of ENSO as a regulator of the tropical and extratropical hydrological cycle.

\section{Glaciers and ice cores}

The tropical Andes represent the largest glaciated area within the tropics. The major palaeoclimatic implications derived from glaciers are the history of their varying extent and the analyses of snow accumulation rates and the stable isotope variations and aerosol content preserved in the ice. While the former aspect is usually reconstructed by the use of geomorphological and geological methods, the latter are studied from geochemical analyses of ice cores. Mountains of the Western Cordillera situated within the "dry diagonal" between $19-27^{\circ} \mathrm{S}$ are not glaciated at present, although they are situated above the $0^{\circ}$ isotherm level. This demonstrates the dominant importance of hydrological changes for glacier variations rather than temperature depressions in the arid part of the Andes (Amman et al., 2001).

In a recent review on Late Pleistocene and Holocene glacier history, Clapperton (2000) provided evidence that glacier highstands during the Late Glacial Maximum (LGM) 
and the Late Glacial show rather consistent ages of ca. 31-18 kaBP and 12-13 kaBP throughout the American Cordillera between Alaska and southern Chile. Clapperton et al. (1997) report about LGM, Late Glacial and early Holocene glacier advances around 34-27 ka BP, 14-13 ka BP and $12-10 \mathrm{kaBP}$, the former two probably corresponding with high lake levels of Palaeolakes Minchin and Tauca on the Bolivian Altiplano. For the tropical Andes, average depressions of the equilibrium line altitude (ELA) of 900-1000 $\mathrm{m}$ during the LGM are reported (Porter, 2001; Hastenrath, 2009), however with huge local deviations. This ELA depression corresponds to a temperature decrease of $5.4 \pm 0.8^{\circ} \mathrm{C}$ during LGM, confirming model results of $6.4+1.52 /-1.28^{\circ} \mathrm{C}$ (Kull et al., 2008). From a $\delta^{18} \mathrm{O}$ isotope record of the Huascarán (Peru) ice core (Figs. 1, 3c), Thompson et al. (2000) conclude that the LGM ended around 17.5 ka BP, with temperature depressions at high elevations in the tropics being colder than today by as much as 8$12^{\circ} \mathrm{C}$. During the Late Glacial, the $\delta^{18} \mathrm{O}$ record from an ice core of Sajama (Figs. 1, 3e) shows a return to nearly glacial conditions, similar in magnitude to Younger Dryas cooling recorded in the Greenland ice cores (Thompson et al., 2000).

Glaciers in Ecuador fluctuated rapidly during the last deglaciation and advanced before $12.5 \mathrm{kaBP}$ and between 10.5-9.0 ka BP (Heine and Heine, 1996). Colombian glaciers advanced during the early Holocene around $11 \mathrm{ka} \mathrm{BP}$ which seems to indicate very humid conditions (Clapperton, 2000). Between 11-9 ka BP, temperature increased to early Holocene maximum conditions that were $1.5-2.0^{\circ} \mathrm{C}$ warmer than during the Late Holocene (Thompson et al., 2000). Interestingly, the ice core records of Huascarán and Sajama (Fig. 3c, e) reveal contrasting temperature histories during the middle and late Holocene. Temperatures at Huascarán seem to have decreased continuously since the early Holocene, while late Holocene temperatures at Sajama seem to have been around $0.8^{\circ} \mathrm{C}$ warmer than during the early Holocene. During the late Holocene, stable isotopes in Peruvian and Bolivian ice cores indicate a warmer period from AD 1140-1250, possibly reflecting the "Medieval Warm Period". A cooler period occurred during AD 1300-1850, correlating with the "Little Ice Age" period of the Northern Hemisphere (Thompson et al., 2003). The Huascarán ice core reveals that the 19th and 20th centuries were the warmest period during the last 6000 years (Thompson et al., 2000).

Compared to the humid Andes, dates of maximum late Pleistocene glacier advances in the arid Andes between 18$25^{\circ} \mathrm{S}$ show a temporal offset. Ammann et al. (2001) calculated ELA depressions of 700-1000 m during a Late Glacial glacier advance period around $13.3 \mathrm{kaBP}$ that correspond to the humid "Tauca" phase of Lake Titicaca and to a glacier advance on the Bolivian Altiplano at $19^{\circ} 50^{\prime} \mathrm{S}$ (Clayton and Clapperton, 1997). In a recent review, Zech et al. (2008) describe glacial maxima to 25-20 ka BP for Bolivia and Late Glacial glacier advances between ca. 17-14 and 13-11.5 ka,

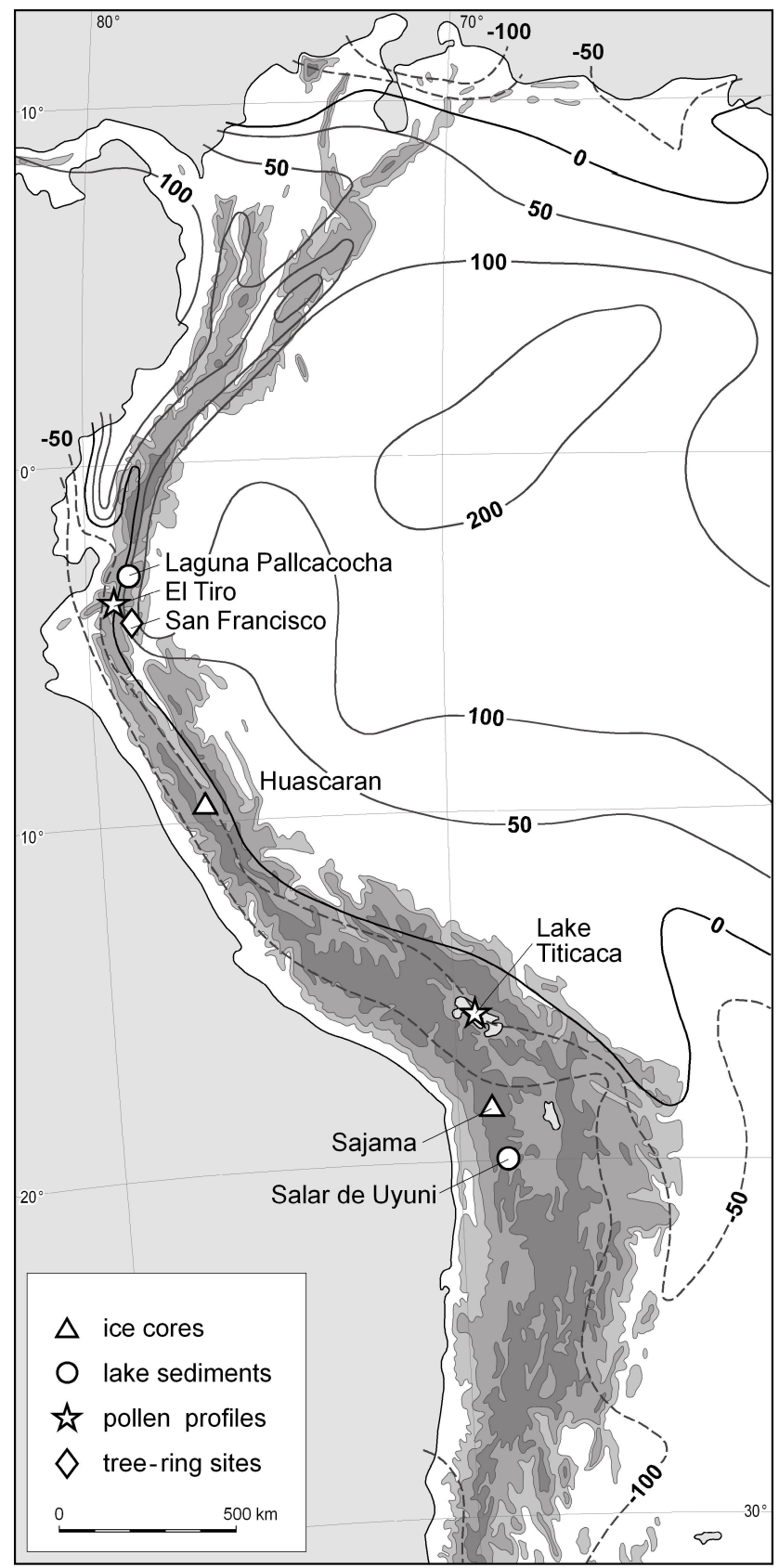

Fig. 1. Mean climatic water balance (in $\mathrm{cm}$; from Henning and Henning, 1984, modified) and location of selected palaeoclimatic study sites along the Andes dealt in the text.

corresponding to the global LGM temperature minimum, Heinrich event 1 and the "Younger Dryas" or "Antarctic Cold Reversal" climatic deteriorations, respectively. The early and middle Holocene were marked by widespread glacier recession, but a return to cooler and more humid conditions apparently occurred after about $5 \mathrm{ka} \mathrm{BP}$. Around $2.6 \mathrm{ka} \mathrm{BP}$, a pronounced glacier advance that is synchronous with higher lake levels on the southern part of the Altiplano ( $27^{\circ} \mathrm{S}$; Grosjean 
et al., 1997) is evident for the south-central Chilean Andes (ca. $29^{\circ} \mathrm{S}$; Grosjean et al., 1998). This increase in effective moisture points to an intensification and northward shift of the westerlies, possibly as a result of lowered solar radiation at around 2.7 BP (van Geel et al., 2000). These results indicate that glacier variations in the arid Andes are mainly controlled by changes in effective moisture in the respective precipitation regimes (tropical summer versus extratropical winter precipitation) and therefore show contrasting advance periods to other glaciated regions of the earth and different regional responses to climate change (Ammann et al., 2001).

During the recent decades, Andean glaciers show dramatic rates of retreat. For instance, Cotopaxi $\left(0^{\circ} 42^{\prime} \mathrm{S}\right)$ lost almost $30 \%$ of its glaciated area during 1976-1997 (Jordan et al., 2005). Ice loss at Chacaltaya glacier in Bolivia $\left(16^{\circ} \mathrm{S}\right)$ and Antizana in Ecuador $\left(0^{\circ} 28^{\prime} \mathrm{S}\right)$ was highest during El Niño events, when summer rainfall on the Altiplano is reduced and incoming solar radiation is strongly increased (Francou et al., 2003, 2004; Garreaud et al., 2003, Favier et al., 2004).

\section{Lake sediments and wetland deposits}

Lake sediment records provide one of the most widely distributed archive along the tropical Andes. Proxies studied in lake sediments include magnetic susceptibility, grain size distribution and content and isotope signature of organic carbon. Age and height of former shorelines also provide valuable palaeoclimate information. Lake histories often show individual characteristics due to very variable watershed size, watershed elevation including or excluding glaciated areas, lake basin geometry, topography and climatic conditions of the surroundings. Nevertheless, some prominent features of past climate changes can be found in the majority of lake records.

Before $192 \mathrm{ka} \mathrm{BP}$ and around 73-30 ka BP, the palaeolakes "Escara" and "Minchin" covered parts of the Altiplano (Fornari et al., 2001). The Salar de Atacama experienced wet periods during $75.8-60.7 \mathrm{kaBP}$ and from $53.4-15.3 \mathrm{ka} \mathrm{BP}$ (wettest phase 26.7-16.5 ka BP), corresponding to palaeolake "Minchin" (Bobst et al., 2001). High LGM levels at Lake Titicaca ended around $21 \mathrm{ka} \mathrm{BP}$ (Baker et al., 2001b). Quite consistently, a humid period during the Late Glacial is detected on the Altiplano (Abbott et al., 2003). Seltzer et al. (2002) argue that drastic changes in magnetic susceptibility and sediment influx in Lake Junin $\left(11^{\circ} \mathrm{S}\right)$ and Lake Titicaca $\left(16^{\circ} \mathrm{S}\right)$ witness early LGM tropical deglaciation which predates glacier retreat from LGM positions in more polar latitudes by several millennia. In the Uyuni-Coipasa Basin on the Bolivian Altiplano (ca. $19^{\circ} 30^{\prime} \mathrm{S}$ ), a Late Glacial humid phase "Tauca" occurred around 15.5-12 ka BP, followed by a the dry "Ticaña" period and a less humid period associated with the "Coipasa" lacustrine phase around 10.5$9.5 \mathrm{ka} \mathrm{BP}$ (Sylvestre et al., 1999). At Salar de Atacama, this early Holocene humid period already occurred at 11.410.2 ka BP (Bobst et al., 2001).

The early Holocene highstand is followed by a more or less pronounced phase of aridity during the middle Holocene, which commenced between 7-6 ka BP (Abbott et al., 2003; Baker et al., 2001b). Along a north-south transect from $14-19^{\circ} \mathrm{S}$, lakes on the Altiplano show a tendency towards a more severe and prolonged middle Holocene arid phase, which ended around $4.8 \mathrm{ka} \mathrm{BP}$ at $11^{\circ} \mathrm{S}$ and around $2.1 \mathrm{ka} \mathrm{BP}$ at $19^{\circ} \mathrm{S}$, suggesting a different behaviour of lakes along this transect (Abbott et al., 2003). After $4.5 \mathrm{ka} \mathrm{BP}$, the level of Lake Titicaca is rising again (Baker et al., 2001b). In the Chilean part of the Altiplano $\left(18^{\circ}-28^{\circ} \mathrm{S}\right)$, small lakes testify a humid Late Glacial-early Holocene period 15.510.2 ka BP and pronounced middle Holocene aridity starting around $8 \mathrm{ka} \mathrm{BP}$ (Grosjean, 1994; Grosjean et al., 1995; Geyh et al., 1999; Valero-Garcés et al., 1996). This middle Holocene dry period in the Atacama derived from lake sediments is contradicted by wetland deposits accumulated in river channels and palaeo-wetland deposits around the Salar de Atacama (Rech et al., 2002): Phases of higher groundwater tables are indicated before $44 \mathrm{ka} \mathrm{BP}, 15.4-9 \mathrm{ka} \mathrm{BP}$ and 8-3 ka BP. This is corroborated by palaeo-wetland sediments from the Bolivian Andes $\left(16^{\circ}-22^{\circ} \mathrm{S}\right)$, which indicate higher water tables around 6-4.5 ka BP, contemporaneous with a lower water level at Lake Titicaca. After an erosion phase around $4 \mathrm{kaBP}$, wetlands expanded around $2.7 \mathrm{ka} \mathrm{BP}$ (Servant and Servant-Vildary, 2003).

\section{Pollen records}

Pollen records allow the reconstruction of the late Pleistocene and Holocene vegetation changes. Due to the small horizontal extension of vegetation zones, climate variations are mainly derived from vertical shifts of altitudinal vegetation belts (Paduano et al., 2003). In the humid Andes, lake sediments and peat bogs offer suitable substrates for pollen analyses. As a consequence of the generally sparse vegetation in the arid Andes, organic sediments providing continuous records of vegetation history are limited to lacustrine sediments. In addition, fossil plant material occurs in the form of rodent middens.

In the humid Andes, vertical lowering of vegetation belts amounts to $1000 \mathrm{~m}$ in the Eastern Cordillera of Colombia (Van der Hammen, 1974) and 1000-1100 m in eastern Ecuador, suggesting a temperature drop of ca. $7.5^{\circ} \mathrm{C}$ during the pleniglacial (between 26-34 ka BP; Bush et al., 1990). In southwestern Ecuador (Cajas National Park, $2^{\circ} 45^{\prime} \mathrm{S}$, $79^{\circ} 10^{\prime} \mathrm{W}, 3700 \mathrm{~m}$ a.s.1.), the Late Glacial (17-11 ka BP) was characterized by herb paramo, reflecting colder and moister conditions than today. The beginning of the Holocene was marked by an expansion of moist mountain forest under a warmer climate than at present. During the Holocene, Polylepis reached its maximum during the middle Holocene 
a)

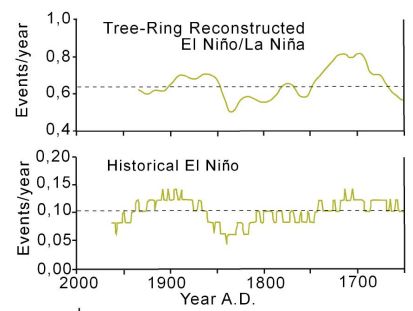

b)

c)

d)
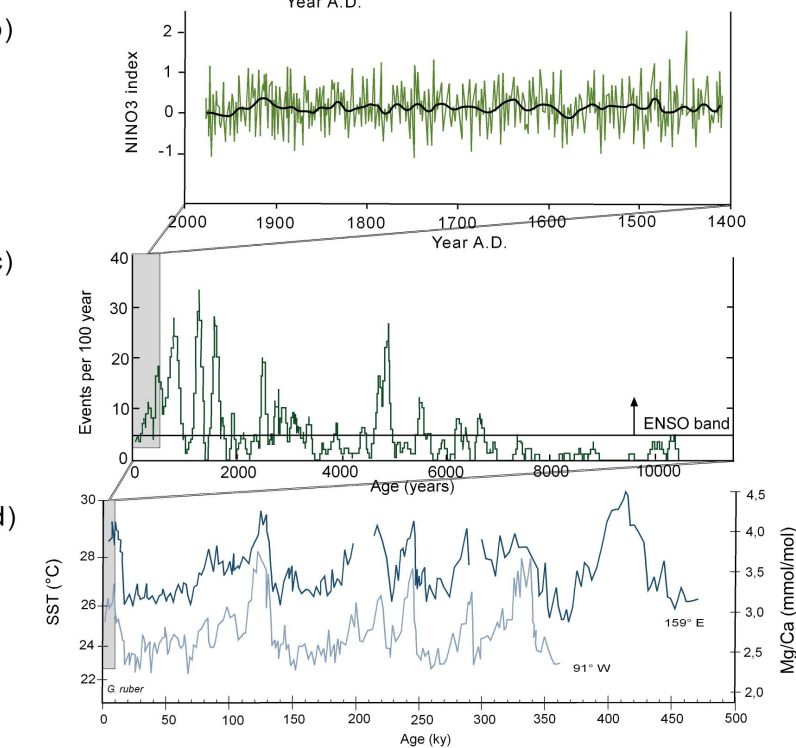

Fig. 2. Time series of ENSO variability during different time windows during the Pleistocene and Holocene. (a) El Niño and La Niña events reconstructed from tree-ring chronologies in Patagonia and central Chile (after Villalba, 1994) and recurrence of moderate to very strong El Niño events reconstructed from archival documents (Quinn and Neal, 1992, after Kitzberger et al., 2001); (b) SST reconstruction for the Niño-3 region derived from tree rings (horizontal line=mean, heavy line is 25-year cubic smoothing spline, from D'Arrigo et al., 2005); (c) number of ENSO events in 100-yr overlapping windows. The solid line denotes the minimum number of events in a 100-yr window needed to produce ENSO-band variance (after Moy et al., 2002); (d) SSTs in the equatorial Pacific at $91^{\circ} \mathrm{W}$ (Cocos Ridge) and $159^{\circ} \mathrm{E}$ (Ontong Java Plateau) derived from $\mathrm{Mg} / \mathrm{Ca}$ relation in planktonic foraminifera shells (from Lea et al., 2000).

(7.5-4 kaBP), when a grass paramo dominated the area above the treeline (Hansen et al., 2003). At site El Tiro in southern Ecuador ( $03^{\circ} 50^{\prime} \mathrm{S}, 79^{\circ} 09^{\prime} \mathrm{W}, 2810 \mathrm{~m}$ a.s.1.), a grass paramo was already developed around $20.1-15.8 \mathrm{ka} \mathrm{BP}$ (Niemann and Behling, 2007; Figs. 1 and 3b). Subparamo herbs and mountain rainforest elements gradually replaced the paramo during 11.2-8.9 ka BP under warmer and wetter conditions than during the Late Glacial. Between 8.9-3.3 ka BP, a mountain rainforest predominated the site which was replaced by the present subparamo vegetation after $3.3 \mathrm{ka} \mathrm{BP}$, indicating slightly warmer and drier conditions during the middle Holocene than during the early and late Holocene (Niemann and Behling, 2007). At Laguna Baja ( $7^{\circ} 42^{\prime} \mathrm{S}$,

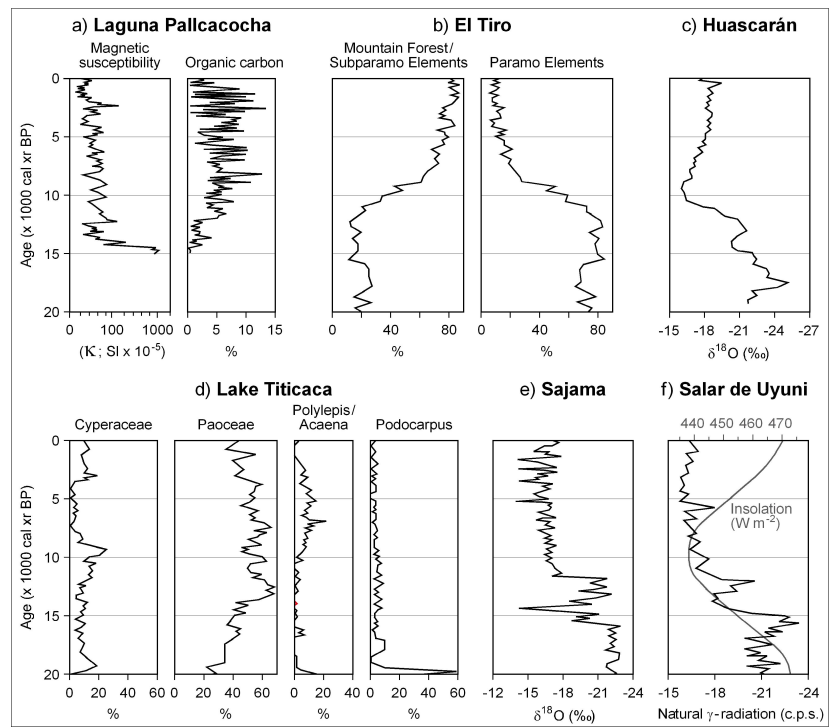

Fig. 3. Palaeoclimate data series from various proxy records for locations from the humid Andes (a-c) and the arid Andes (d-f). Site locations are shown in Fig. 1. (a) Magnetic susceptibility and organic carbon in a sediment core from Laguna Pallcacocha, southwestern Ecuador (from Rodbell et al., 1999, changed); (b) percentage of pollen grains of mountain forest and subparamo elements versus paramo elements in a peat bog at El Tiro, southern Ecuador (from Niemann and Behling, 2007); (c) $\delta^{18} \mathrm{O}$ isotope record of the Huascarán ice core (from Thompson et al., 2000, changed); (d) percentage of pollen grains of various plant taxa from Lake Titicaca (from Paduano et al., 2003, changed); (e) $\delta^{18} \mathrm{O}$ isotope record of the Sajama ice core (from Thompson et al., 2000, changed); (f) natural $\gamma$-radiation of sediments from Salar de Uyuni and January palaeoinsolation at $15^{\circ} \mathrm{S}$ latitude (from Baker et al., 2001a; Berger and Loutre, 1991, changed).

$77^{\circ} 32^{\prime} \mathrm{W}, 3575 \mathrm{~m}$ a.s.1.) in northern Peru, a warm and moist climate supported an open mixed mountain forest during the Late Glacial period before ca. $12 \mathrm{kaBP}$. An expansion of paramo at the expense of the mixed mountain forest occurred during 11.6-10 ka BP, suggesting a cooler and/or drier climate. After $10 \mathrm{kaBP}$, the transition to wetter and warmer Holocene climate leads to the replacement of the paramo vegetation by a wet mountain forest. After around $6 \mathrm{kaBP}$, the increase of Poaceae pollen and the decrease of ferns and trees might indicate slightly drier conditions during the middle Holocene (Hansen and Rodbell, 1995). At nearby Laguna de Chochos ( $7^{\circ} 38^{\prime} \mathrm{S}, 77^{\circ} 28^{\prime} \mathrm{W}, 3285 \mathrm{~m}$ a.s.1.), mountain wet forest elements (Polylepis, Podocarpaceae) expanded around 11500 cal. yr BP, contemporaneous with Laguna Baja. A dry event is evident between 9500-7300 cal. yr BP. Afterwards, forest elements decreased in abundance, giving room to an open, park-like habitat. However, more intensive land use by humans might also have had an influence on vegetation during the late Holocene (Bush et al., 2005). 
In the dry Andes, Maldonado et al. (2005) studied the pollen content in rodent middens on a west-east transect along ca. $25^{\circ} 30^{\prime} \mathrm{S}$ from the Atacama Desert to the Altiplano. The sites are located in the transition zone between the westerlies and the tropical easterlies that influence the lower and upper studied sites, respectively. According to the temporal distribution of midden sediments and pollen types found therein, more winter precipitation occurred at $>52,40-33$, and 24-17 ka cal. BP, more precipitation in both seasons at $17-14 \mathrm{kacal}$. BP, and more summer precipitation from 14-11 ka cal. BP. Periods without midden findings are interpreted as arid periods that occurred during 52-40, 3324 and 11-ca. $1 \mathrm{kaBP}$. A rodent midden study by Latorre et al. (2003) corroborates a more humid period during the Late Glacial-Holocene transition (13.5-9.6 ka BP) with more abundant grass cover and species richness in the Chilean Altiplano. Holocene arid conditions commenced around 9.6 ka BP, but were interrupted by a more humid period during 7.6-3.2 ka BP, before modern hyperarid conditions prevailed. Pollen content from a sediment core from Lake Titicaca $\left(16^{\circ} 08^{\prime} \mathrm{S}, 69^{\circ} 09^{\prime} \mathrm{W} ; 3810 \mathrm{~m}\right.$ a.s.l. water level, $152 \mathrm{~m}$ water depth; Fig. 1) indicates a lowering of the vertical vegetation belt of $1000-1300 \mathrm{~m}$ before $21.5 \mathrm{kaBP}$, suggesting a cooling of $5-8^{\circ} \mathrm{C}$ during LGM. Between $17.7-6 \mathrm{ka} \mathrm{BP}$, a gradual and continuous warming took place, as reflected by an increase of Poaceae pollen (Fig. 3d). During the middle Holocene (7.9-3.1 ka BP), a pronounced dry period occurred which is reflected by a decreasing pollen concentration of Cyperaceae growing in littoral marshes. Those marshes probably dried out and groves of Polylepis expanded (Paduano et al., 2003, Fig. 3d). Between 3.7-3.3 k BP, climate became more humid again as indicated by increasing Cyperaceae and decreasing Polylepis/Acaena pollen concentration.

\section{Dendrochronology and dendroecology}

Although dendroclimatology is a widely applied technique for deriving high-resolution palaeoclimate reconstructions in temperate mountain environments, very little tree-ring information is available from tropical mountain areas. A vast number of climate sensitive tree-ring chronologies used for reconstructing tropical climate variations were in fact developed from subtropical regions with pronounced rainfall seasonality or semiarid sites in temperate climates. Therefore, tree-ring based reconstructions of the climate history of the inner tropics are so far mainly based on climatic teleconnections between the inner tropics and adjacent subtropical regions. For example, tree-ring networks comprising drought sensitive conifers from Mexico and southwestern North America were used to reconstruct winter precipitation in the respective regions, the temporal variability of SSTs, the Southern Oscillation Index (SOI) or the Pacific Decadal Oscillation (PDO) (Stahle et al., 1998; Biondi, 2001; Díaz et al., 2001; Cleaveland et al. 2003 and several papers in Diaz and Markgraf, 1992; Gedalof et al., 2002). A reconstruction of Niño-3 SSTs from D'Arrigo et al. (2005; Fig. 2b) using north American tree-ring chronologies shows decreased variability in the cold 1600 s to early 1700 s which coincides with a period of low northern Hemispheric solar insolation, the late Maunder Minimum. A reconstructed event series of El Niños/La Niñas from South American tree-ring sites (Villalba, 1994) shows a remarkable similarity with an event series derived from historical archival documents (Quinn and Neal, 1992; Fig. 2a).

However, climatic teleconnections between the semiarid subtropics and the inner tropics are not necessarily constant during different climatic episodes (D'Arrigo et al., 2005). Therefore, multicentury ENSO reconstructions from the tropical Andes are urgently needed. While the arid tropical Andes are almost devoid of trees, the humid tropical Andes between Venezuela and northern Peru are carrying mountain rainforests extremely rich in tree species. A serious obstacle to tropical dendroclimatology, however, is the fact that the majority of tropical tree species do not form distinct anatomical growth boundaries due to the weak or absent annual climate seasonality. While temperature in the tropics generally vary more along altitudinal gradients than within the annual cycle, rainfall patterns may show distinctive seasonal or sub-annual variations that may initiate the formation of detectable growth boundaries. These can be initiated directly, by forcing cambial cells to dormancy due to lack of water supply or indirectly, by determining phenological phases of fruiting, flowering or leaf shedding in deciduous species (Bräuning et al., 2008a). Hence, the connections between tree growth rates, formation of different seasonal wood tissues and their triggering environmental factors have to be minutely analysed before long tree-ring records can be established.

During the recent years, considerable methodological progress was achieved in detecting and analysing annual growth increments in tropical tree species (Vetter, 2000; Worbes, 2002). More and more tropical tree species are discovered to form annual or subannual growth boundaries that can be used for dendroecological analysis. E.g., in the lowlands of northern Peru, El Niño events are coupled with abundant rainfall which leads to drastic increases of growth rates in the deciduous tree species Bursaera graveolens and Prosopis pallida (Rodriguez et al., 2005). Nevertheless, treering chronologies from the tropical Andes are still extremely rare or cover less than one century. Exceptions are ring width chronologies of Polylepis tarapacana from the Bolivian Altiplano that grow potentially several centuries old. In warm/dry El Niño (cool/moist La Niña years), P. tarapacana exhibits positive (negative) growth anomalies reflecting spectral ENSO characteristics and showing spatial correlation patterns related to the atmospheric circulation modulated by the tropical Pacific (Christie et al., 2008; Barichivich et al., 2008). In this paper, we will focus on dendrochronology in the humid part of the tropical Andes. 
A preliminary ring-width chronology derived from $\mathrm{Ce}$ drela cf. montana was developed in the Reserva Biologica San Francisco in southern Ecuador (Figs. 1 and 5). Growth boundaries of Cedrela consist of marginal parenchyma bands that are sometimes difficult to detect. Moreover, wood samples collected with increment cores often include missing rings and false rings, making synchronisation (Stokes and Smiley, 1968) between ring-width curves of different trees challenging and time consuming. Most of the trees collected were younger than 50 years, however, some trees older than 160 years (Fig. 4) were found. As can also be seen from Fig. 4, a reliable quality of the Cedrela chronology is only reached after ca. 1950, when the chronology includes more than 20 individual tree-ring series and the recommended threshold of the "expressed population signal" (a measure of the reliability of a tree-ring chronology, Wigley et al., 1984) is passed. This means that the individual ring-width curves of different trees show strong individual variations (possibly partly due to stand dynamics) and a weak common climate signal which makes the collection of high sample numbers necessary.

Intra-seasonal growth variations of Cedrela show low growth rates or even stem shrinkage after short periods without rainfall during the growing season (Fig. 5). The magnitude of stem shrinkage is related to the maximum vapour pressure deficit (Volland-Voigt et al., 2009), indicating that even in a humid climate with more than $2100 \mathrm{~mm}$ of annual rainfall tree growth can be limited by water availability (Bräuning et al., 2008b). Due to very short available instrumental climate data series, classical statistical methods for analysing climate-growth relationships are not yet applicable for the Cedrela chronology and await further efforts. Increasing knowledge about suitable tree species for dendrochronological studies and the application of stable isotope analyses of ${ }^{13} \mathrm{C},{ }^{18} \mathrm{O}$ and ${ }^{2} \mathrm{H}$ of tree rings or growth zones (e.g. Poussart et al., 2004; von Schnakenburg et al., 2008) may help to identify annual growth boundaries and to develop long, high-resolution climate-sensitive data series. For example, $\delta^{18} \mathrm{O}$ variations in Prosopis growing in the western Andean foreland show drastic variations during the warm phases of an ENSO event, (Evans and Schrag, 2004; Rodriguez et al., 2005).

\section{Discussion}

Each of the presented palaeoclimate reconstructions suffers from specific shortcomings that require methodological considerations of the individual natural archive. Dates about late Pleistocene and Holocene glacier advance phases are generally of low temporal resolution and precision. They are often derived from ${ }^{14} \mathrm{C}$ dating of glacier deposits or organic material covered by glacial or glaciofluvial sediments during glacier advances, implying the risk of dating reworked and redeposited material (ex situ) of older age than the glacier

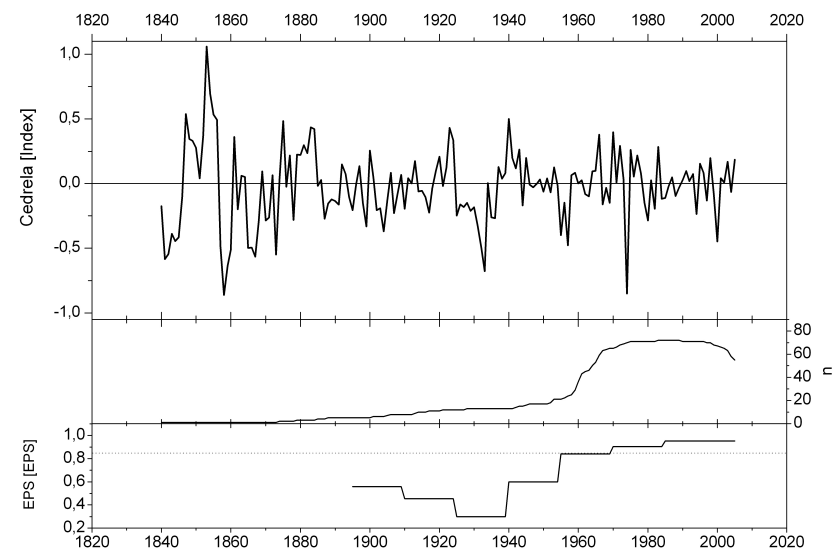

Fig. 4. Growth index values of Cedrela cf. montana, number of trees sampled and expressed population signal (EPS).

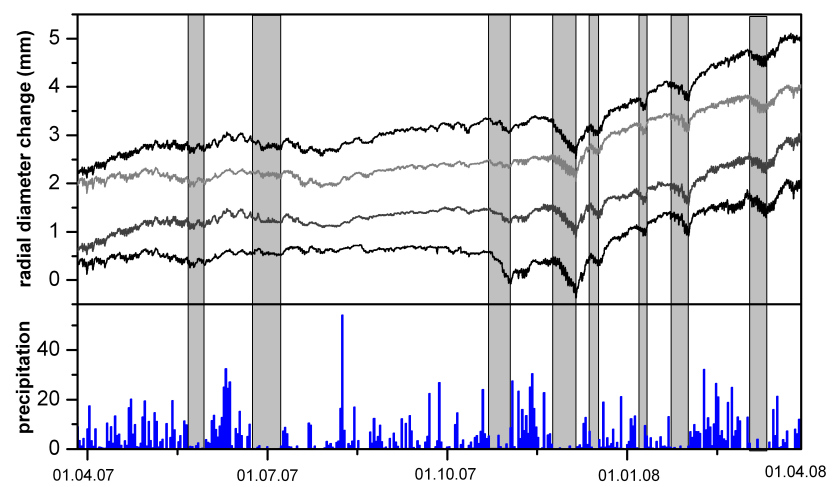

Fig. 5. Stem diameter variations of four Cedrela trees in southern Ecuador (upper panel) and daily sums of precipitation (lower panel). Longer periods without rainfall that occur during the leafy season of Cedrela are marked by grey bars. During roughly August to November, Cedrela is partly shedding the leaves (Bräuning et al., 2008).

stage it is ascribed to. In comparison with mountain regions of temperate climate zones, the number of dated glacier deposits in tropical mountain regions is still low and needs confirmation. General methodological difficulties in dating glacier deposits arise from possibly unclear stratigraphic connections between dated sediments due to the occurrence of hiatuses and issues of calibrating radiocarbon derived ages. In the arid Andes, radiocarbon dating is further hampered by lack of datable organic material in glacial deposits. Furthermore, glaciers in the arid tropics are more sensitive to precipitation changes whereas glaciers in the humid tropics react positively to temperature depressions (Favier et al., 2004; Kull et al., 2008; Hastenrath, 2009), leading to synchrony or asynchrony of their maximum ice extent during global LGM temperature minima. The increasing number of ${ }^{10} \mathrm{Be}$ exposure dates of glacier deposits might provide a higher data density about former glacier variations in the 
tropical Andes in the near future; however, methodological uncertainties still have to be overcome (Zech et al., 2008).

General problems of ice core interpretation concern the dating accuracy of deeper ice layers which are often modeled, whereas the upper annual ice layers are usually determined by counting annual dust layers or by interannual isotope variations. Although oxygen isotope variations among Andean ice cores are strongly coherent during the 20th century (Hoffmann et al., 2003), their palaeoclimatological interpretation is still under debate. Bradley et al. (2003) emphasize that during El Niño and La Niña situations, net accumulation on Sajama ice core strongly varies between different years and thus represents different seasonal climate windows (Hardy et al., 2003). During extreme El Niño years, the complete amount of snow accumulated during a summer might be lost (Hardy et al., 2003). Therefore there is a potential risk that during longer periods of warm and arid conditions, some ice layers might have been melted away, leading to discontinuous and climatically biased records. $\delta^{18} \mathrm{O}$ variations in the Sajama ice core record show positive correlations with eastern Pacific sea surface temperatures and negative correlations with snow accumulation and precipitation amounts, indicating the influence of an "amount effect" on isotope content in precipitation (Bradley et al., 2003; Hardy et al., 2003). The existence of the 'amount effect' generally leads to a predominant precipitation signal in tropical $\delta^{18} \mathrm{O}$ ice-core records. This is corroborated by the coherence of the Sajama $\delta^{18} \mathrm{O}$ record with a $\gamma$ radiation-record from sediments of the Salar de Uyuni $\left(20^{\circ} \mathrm{S}, 3650 \mathrm{~m}\right)$ during the past 25000 years (Baker et al., 2001a; Fig. 3e and f). On the other hand, an "amount effect" might be pretended by the drastically lowered (ca. $2 \mathrm{~km}$ ) elevation of the condensation level of the air masses due to colder temperatures under glacial conditions (Thompson et al., 2000). Hence, reconstructions of the amount of glacial cooling are not based on a simple cause-and-effect mechanism and derived temperature depressions might be exaggerated.

Archives of lower time resolution are presented by lacustrine sediments. In addition to the general problem of calibrating radiocarbon dates, dating of lacustrine sediments in closed lake systems may be hampered by the "reservoir effect". This implies that the present lake water does not reveal modern radiocarbon ages due to exchange of carbon isotopes with groundwater or with the atmosphere after postdepositional exposure. Hence, each lake shows specific and timevariable (e.g. due to changing water depth) deviations of ${ }^{14} \mathrm{C}$ ages from real ages of sediment formation which makes synchronization between different records difficult (Geyh et al., 1999). E.g., the reservoir effect for precipitated carbonates in different lakes on the Chilean Altiplano varies from 1200 to $>8000$ years (Geyh et al., 1999). Besides climate, lake levels may strongly be influenced by lake basin history, as it is indicated by inverse trends in depths of palaeolakes in the Titicaca Basin (older lakes are deeper than younger lakes) and on the central Altiplano (younger lakes are deeper than older lakes) since the Pleistocene. This phenomenon is probably caused by the erosion of the threshold between the two basins by the Desaguadero river, leading to water overflow from north south and does not reflect palaeoclimatic evolution (Fornari et al., 2001).

Pollen analyses represent another palaeoclimatic archive of relatively low (usually decadal or centennial) time resolution. The determination of pollen grains to plant taxonomic groups is often limited to the family or genus level. Usually, age-depth functions of pollen profiles are extrapolated between a limited number of ${ }^{14} \mathrm{C}$ ages, assuming constant rates of peat growth between the dated horizons. This may lead to unclear dating precision. Depending on the distance between the analyzed pollen samples within a profile, shortterm climatic events might be overlooked or might also not be reflected by the long-term vegetation development. For example, the Younger Dryas (12.5-11 ka BP) that is manifested in the ice cores of Sajama and Huascarán (Thompson et al., 2000) is neither reflected in the pollen record of nearby Lake Titicaca (Paduano et al., 2003; Fig. 3d) nor by pollen data suggesting cooler conditions than during the Late Glacial in the Peruvian Andes (Bush et al., 2005).

Beside the plant species locally present around a study site, a certain influence of far distance transported pollen is always present. The proportion of far-distance transported pollen grains from lower vegetation belts may be increased during glacial times with low pollen production rates. For example, a peak of the mountain forest species Podocarpus pollen occurs at $20 \mathrm{ka} \mathrm{BP}$ at Lake Titicaca (Fig. 3d, Paduano et al., 2003, for the humid Andes see Bush et al., 2005), being a clear indicator of far-distance pollen transport. In humid environments where mountain rainforest elements might be relatively close, but growing in a different altitudinal vegetation belt, identification of far-distance transported pollen might be more difficult. This could result in an overestimation of temperature depressions interpreted from vertical shifts of vegetation belts. E.g., Bush et al. (1990) estimate a cooling during $33-30 \mathrm{kaBP}$ of as much as $7.5^{\circ} \mathrm{C}$ from the occurrence of mountain forest taxa in deposits from the Eastern Andean foreland in Ecuador. However, it seems sometimes too simplistic to interpret vertical shifts of geoecological zones only as a result of temperature variations and quasi-linear shifts of vegetation belts without considering concomittant prominent changes in moisture conditions or changes in plant community structure in a different environmental setting.

In addition, the pollen taxa representing the super-puna (Puna brava) vegetation belt strongly resemble those of the puna vegetation. Thus, changes in high-elevation vegetation belts can only be distinguished by changing pollen concentration and amount of far-distance pollen (Paduano et al., 2003) rather than by identification of clear indicator taxa. Pollen data reflect ecological changes at a site and thus do not only mirror climate changes, but also integrate other influences on vegetation like naturally or anthropogenically caused fires or other types of human activity. Indications for 
intensive human impact might be derived from the number of charcoal particles (e.g. Niemann and Behling, 2007). From this, a rather intensive impact of man on vegetation in the tropical Andes can be inferred probably as early as $8000 \mathrm{BP}$ in southern Ecuador (Niemann and Behling, 2007), and since at least $4000 \mathrm{BP}$ around Lake Titicaca (Paduano et al., 2003). Nevertheless, human occupation even of the arid Andes has been continuous (although probably low) even during the very arid middle Holocene from $8000-4800 \mathrm{BP}$, the so called "Silencio Arqueologico" (Grosjean et al., 1997).

Rodent middens are able to represent local vegetation structures and species composition quite reliably (Latorre et al., 2003), but their distribution in time is discontinuous, providing "snapshots" of local vegetation at discrete intervals (Betancourt et al., 2000; Paduano et al., 2003), which at the present state are poor in temporal replication and need further refinement (Latorre et al., 2006). Rodent middens might have been repeatedly recolonized during suitable periods and might completely lack during other periods of extremely unfavourable living conditions and sparse vegetation cover. Thus, they tend to overrepresent moist climate phases with high rodent populations (Paduano et al., 2003; Latorre et al., 2006). Fossil plant records derived from rodent middens around the Salar de Atacama testify the humid period during the Late Glacial (16.2-10.5 ka BP), but contradict evidence for the contemporaneous hyperarid period during the middle Holocene at Lake Titicaca during 8-3 ka BP (Betancourt et al., 2000; Latorre et al., 2003). These discrepancies might arise from changes in palaeocirculation that affect different parts of the topographically complex region of the arid Andes in different ways. On the other hand, dating problems or different response times and sensitivity of the individual archives may cause a decoupling of the reconstructed proxy records (Latorre et al., 2003; Grosjean et al., 2003). The latter assumption seems very plausible, since for example lake systems and peat bogs show a much longer response time than vegetation-based proxies like rodent middens. Thus, the discrepancy of the mid-holocene dry period might possibly result from a climate with generally dry conditions with superimposed moist years. These favourable years must have occurred in a frequency high enough to guarantee the survival of animal and plant species, but low enough not to change the long-term hydrological conditions (Grosjean et al., 2003).

According to the earth's precessional cycle, maximum summer (January) insolation at $15^{\circ} \mathrm{S}$ occurred around 20 ka BP (Berger and Loutre, 1991, Fig. 3f), synchronously with more humid conditions at Salar de Uyuni and Sajama (Baker et al., 2001a, Fig. 3e and f) as well as on Lake Titicaca (Bobst et al., 2001). However, the present and $90 \mathrm{ka} \mathrm{BP}$ insolation maxima do not correspond to highstands of lake Titicaca (Bobst et al., 2001), incidating that summer insolation is not the major driving force of summer rainfall on the Altiplano (Rech et al., 2002; Sylvestre et al., 1999; Kull and Grosjean, 1998). There is broad agreement between the vari- ous palaeoclimatic records mentioned about the occurrence of a humid period during the Late Glacial-Holocene transition, roughly between $17.5-9 \mathrm{kaBP}$, interrupted by a dry spell during 14.1-13 ka BP. This humid period can only be explained by an increase of summer precipitation brought to the arid Andes via the South American summer monsoon. The humid Late Glacial period as well as the relatively dry conditions of present time are clearly out of phase with the insolation input (Sylvestre et al., 1999; Fig. 3f). Therefore, variations in solar radiation can not explain the vast climatic variations in the tropical Andes since the Late Pleistocene, although the time-transgressive behaviour of the late Holocene humid phase in Altiplano lakes from north to south has been interpreted as a consequence of orbital forcing as a southward shift of maximum summer insolation and wet-season convection (Abbott et al., 2003). However, gradual, orbital induced insolation changes might initiate abrupt and nonlinear responses of the ocean-atmosphere system, i.e. ENSO behaviour (Clement et al., 2001). La Niña situations lead to increased convection and rainfall over the Altiplano whereas during El Niño conditions dry westerly winds dominate (Garreaud et al., 2003).

Very probably, external factors in the surrounding of the Altiplano mainly controlled climate variations in the arid Andes. During the Late Glacial, these factors include warmer sea surface temperatures and increasing moisture availability in the Gran Chaco region and in the Amazon Basin after the re-establishment of the tropical rainforest that probably contributed to a higher convective activity over the Altiplano. Probably, a shift in strength and position of the ITCZ (Haug et al., 2001) and the Bolivian High lead to enhanced easterly flow over the Altiplano (Kull and Grosjean, 1998; Garreaud et al., 2003; Kull et al., 2008). Via sea surface temperature gradients and zonal pressure fields, extratropical climatic events and boundary conditions also have a strong influence on tropical Andean climate (Baker et al., 2001a, b; Garreaud et al., 2003). Contemporaneous with the LGM insolation maximum, extensive Antarctic sea ice formation might have lead to a shift of the westerly wind belt, leading to increased winter precipitation as far north as northern Chile (Stuut and Lamy, 2004). Servant and Servant-Vildary (2003) argue that fine-grained wetland sediments in the Bolivian Andes suggest regular rainfall brought from low-level coldair incursions from higher latitudes as a consequence of a more northerly position of the Bolivian High during summer. The late Holocene precipitation regime with its exclusively convective precipitation during austral summer thus seems to have established only around $4.5 \mathrm{kaBP}$, after the present ENSO variability had developed.

Tree-ring studies are still in a pioneering state in the tropical Andes. First multi-century long tree-ring chronologies from high-elevation Polylepis tarapacana correlate well with climatic variables, but more work is needed to understand the tree physiological basis of the quite unusual growth-climate response revealing a pronounced bi-annual 


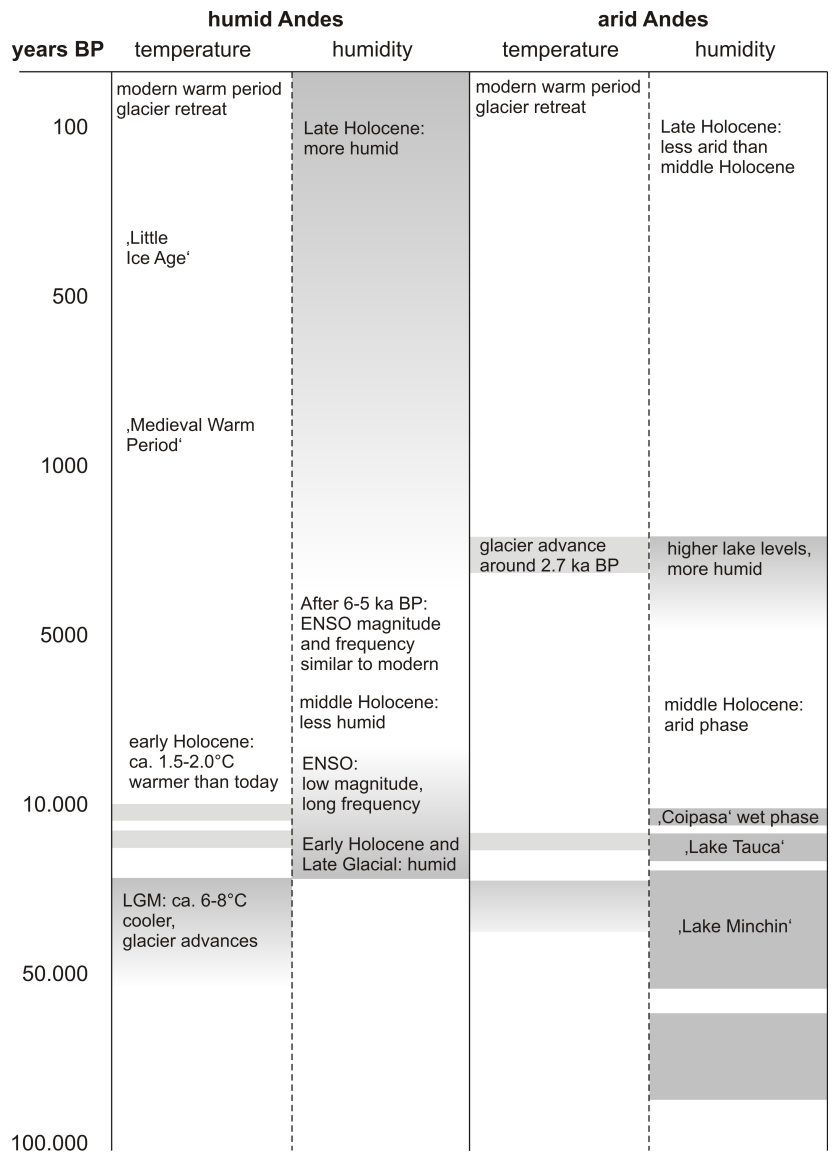

Fig. 6. Overview of climate changes in the humid and arid Andes during the late Pleistocene.

pattern of reversed sign (Christie et al., 2008). The same applies for the humid Andes, where first ring-width chronologies are becoming available from deciduous tree species. Presenly available tree-ring chronologies are rather short. However, radiocarbon dating of the innermost rings of the conifer Prumnopitys montana (Podocarpaceae) from southern Ecuador revealed ages of $418 \pm 35$ years BP (sample no. Erl-12870), demonstrating the potential for developing long tree-ring series also from the humid tropics. Thus, treering studies show a much higher potential for the reconstruction of tropical mountain climate during the last centuries than it might have been expected only a few years before.

\section{Conclusions}

Figure 6 provides an overview of what can be derived about changes of temperature and moisture conditions in the humid and arid parts of the Andes from the findings described above. In general, variations in moisture conditions are better recorded in the arid Andes, whereas more archives of temperature variations are available from the humid Andes. In the previous discussion, however, it has been demonstrated that the understanding of the physical nature of some palaeoclimate proxies (e.g. stable isotope variations in ice cores) is not yet fully understood and that dating uncertainties hamper synchronization between palaeoclimate records from different archives. Instead of recording simple meteorological variables like temperature or precipitation (which is appreciated by climate modellers), some proxies integrate complex environmental signals rather than acting like "palaeothermometers" or "palaeopluviometers". This is one reason why calibration statistics between climate proxies and instrumental climate records often do not explain more than 30-60\% of the common variance. On the other hand, the linkage between a proxy and a climate variable does not need to be constant over time if climatic conditions change. A proxy might change its seasonality and/or its sensitivity towards a certain environmental factor and may react sensitive to different climatic forcings at different time scales (Latorre et al., 2006). Biological proxies are not only sensitive to climate variations, but also to human impact, biological migration or competitive stress. The same environmental change may influence different proxies in different ways, and proxies might react to a climate change with a different response time (tree rings react immediately, glacier length changes moderately fast, vegetation and lake level changes slowly). On the other hand, different palaeoclimatic settings might provocate identical behaviour of a proxy at different times (e.g., lake levels may rise as a result of increased La Niña situations or of southward shift of the ITCZ). Thus, combining various proxy records as a chronological crosscheck, for complementation of different seasonal information and time resolution seems essential to unravel climatic history. The present density of palaeoclimatological information is not yet sufficient to derive a comprehensive picture of past environmental changes for such a complex environment like the tropical Andes.

Acknowledgements. The author is indebted to the European Geophysical Union to support his participation of the 4th Alexander von Humboldt International Conference in Santiago de Chile. The funding of the German Science Foundations (DFG) for project BR $1895 / 14-1$ is also acknowledged.

Edited by: R. Garraud

Reviewed by: two anonymous referees

\section{References}

Abbott, M. B., Wolfe, B. B., Wolfe, A. P., Seltzer, G. O., Aravena, R., Mark, B. G., Polissar, P. J., Rodbell, D. T., Rowe, H. D., and Vuille, M.: Holocene paleohydrology and glacial history of the central Andes using multiproxy lake sediment studies, Palaeogeogr. Palaeocl., 194, 123-138, 2003.

Amman, C., Jenny, B., Kammer, K., and Messerli, B.: Late Quaternary glacier response to humidity changes in the arid Andes of Chile (18-29 S), Palaeogeogr. Palaeocl., 172, 313-326, 2001.

Baker, P. A., Rigsby, C. A., Seltzer, G. O., Fritz, S. C., Lowenstein, T. K., Bacher, N. P., and Veliz, C.: Tropical climate changes 
at millennial and orbital timescales on the Bolivian Altiplano, Nature, 409, 698-701, 2001a.

Baker, P. A., Seltzer, G. O., Fritz, S. C., Dunbar, R. B., Grove, M. J., Tapia, P. M., Cross, S. L., Rowe, H. D., and Broda, J. P.: The history of South American tropical precipitation for the past 25000 years, Science, 291, 640-643, 2001b.

Barichivich, J., Sauchyn, D. J., and Lara, A.: Climate signals in high elevation tree-rings from the semiarid Andes of northcentral Chile: Responses to regional and large-scale variability, Palaeogeogr. Palaeocl., doi:10.1016/j.palaeo.2007.10.033, in press, 2008.

Berger, A. and Loutre, M. F.: Insolation values for the climate of the last 10 Million years, Quaternary Sci. Rev., 10, 297-317, 1991.

Betancourt, J. L., Latorre, C., Rech, J. A., Quade, J., and Rylander, K. A.: A 22000-year record of monsoonal precipitation from Northern Chile's Atacama desert, Science, 289, 15421546, 2000.

Biondi, F.: A 400-year tree-ring chronology from the tropical treeline of North America, Ambio, 30, 162-166, 2001.

Bradley, R. S., Vuille, M., Hardy, D., and Thompson, L. G.: Low latitude ice cores record Pacific sea surface temperatures, Geophys. Res. Lett., 30, 1174, doi:10.1029/2002GL016546, 2003.

Bobst, A. L., Lowenstein, T. K., Jordan, T. E., Godfrey, L. V., Ku, T.-L., and Luo, S.: A 106 ka paleoclimate record from drill core of the Salar de Atacama, northern Chile, Palaeogeogr. Palaeocl., 173, 21-42, 2001.

Bräuning, A., Homeier, J., Cueva, E., Beck, E., and Günter, S.: Growth dynamics of trees in tropical mountain ecosystems, Ecol. Stud., 198, 291-302, 2008a.

Bräuning, A., von Schnakenburg, P., Volland-Voigt, F., and Peters, T.: Seasonal growth dynamics and its climate forcing in a tropical mountain rain forest in southern Ecuador, TRACE - Tree Rings in Archaeology, Climatology and Ecology, 6, 27-30, 2008b.

Bush, M. B., Colinvaux, P. A., Wiemann, M. C., Piperno, D. R., and Liu, K.-B: Late Pleistocene temperature depression and vegetation change in Ecuadorian Amazonia, Quaternary Res., 34, 330-345, 1990.

Bush, M. B., Hansen, C. S., Rodbell, D. T., Seltzer, G. O., Young, K. R., Leon, B., Abott, M. B., Silman, M. R., and Gosling, W. D.: A 17000-year history of Andean climate and vegetation change from Laguna de Chochos, Peru, J. Quaternary Sci., 20, 703-714, 2005.

Christie, D. A., Lara, A., Barichivich, J., Villalba, R., Morales, M. A., and Cuq, E.: El Niño-Southern Oscillation signal in the world's highest-elevation tree-ring chronologies from the Altiplano, Central Andes, Palaeogeogr. Palaeocl., doi:10.1016/j.palaeo.2007.10.033, in press, 2008.

Clapperton, C. M., Clayton, J. D., Benn, D. I., Marden, C. J., and Argollo, J.: Late Quaternary glacier advances and palaeolake highstands in the Bolivian Altiplano, Quatern. Int., 38-39, 4959, 1997.

Clapperton, C. M.: Interhemispheric synchroneity of marine oxygen isotope stage 2 glacier fluctuations along the American cordilleras transect, J. Quaternary Sci., 15, 435-468, 2000.

Clayton, J. D. and Clapperton, C. M.: Broad synchrony of a Late Glacial glacier advance and the highstand of paleolake Tauca in the Bolivian Altiplano, J. Quaternary Sci., 12, 169-182, 1997.

Cleaveland, M. K., Stahle, D. W., Therrell, M. D., Villanueva-Diaz, J., and Burns, B. T.: Tree-ring reconstructed winter precipita- tion and tropical teleconnections in Durango, Mexico, Climatic Change, 59, 369-388, 2003.

Clement, A. C., Seager, R., and Cane, M. A.: Suppression of El Niño during the mid-Holocene by changes in the earth's orbit, Paleoceanography, 15, 731-737, 2000.

Clement, A. C., Cane, M. A., and Seager, R.: An orbitally driven tropical source of abrupt climate change, J. Climate, 14, 23692375, 2001.

D’Arrigo, R., Cook, E. R., Wilson, R. J., Allan, R., and Mann, M. E.: On the variability of ENSO over the past six centuries, Geophys. Res. Lett., 32, L03711, doi:10.1029/2004GL0220554, 2005.

Diaz, H. F. and Markgraf, V.: El Niño. Historical and paleoclimatic aspects of the Southern Oscillation, Cambridge University Press, Cambridge, 1992.

Díaz, S. C., Touchan, R., and Swetnam, T. W.: A tree-ring reconstruction of past precipitation for Baja California Sur, Mexico, Int. J. Climatol., 21, 1007-1019, doi:10.1002/joc.664, 2001.

Evans, M. N. and Schrag, D. P.: A stable isotope-based approach to tropical dendroclimatology, Geochim. Cosmochim. Ac., 68, 3295-3305, 2004.

Favier, V., Wagnon, P., and Ribstein, P.: Glaciers of the outer and inner tropics: A different behaviour but a common response to climatic forcing, Geophys. Res. Lett., 31, L16403, doi:10.1029/2004GL020654, 2004.

Fornari, M., Risacher, F., and Féraud, G.: Dating of paleolakes in the central Altiplano of Bolivia, Palaeogeogr. Palaeocl., 172, 269-282, 2001.

Francou, B., Vuille, M., Wagnon, P., Mendoza, J., and Sicart, J.E.: Tropical climate change recorded by a glacier in the central Andes during the last decades of the twentieth century: Chacaltaya, Bolivia, $16^{\circ} \mathrm{S}$, J. Geophys. Res., 108(D5), 4154 , doi:10.1029/2002JD002959, 2003.

Francou, B., Vuille, M., Favier, V., and Cáceres, B.: New evidence for an ENSO impact on low-latitude glaciers: Antizana 15, Andes of Ecuador, $0^{\circ} 28^{\prime}$ S, J. Geophys. Res., 109, D18106, doi:10.1029/2003JD004484, 2004.

Garreaud, R., Vuille, M., and Clement, A. C.: The climate of the Altiplano: observed current conditions and mechanisms of past changes, Palaeogeogr. Palaeocl., 194, 5-22, 2003.

Garreaud, R. D., Vuille, M., Compagnucci, R., and Marengo, J.: Present-day South American climate, Palaeogeogr. Palaeocl., doi:10.1016/j.palaeo.2007.10.032, in press, 2008.

Gedalof, Z., Mantua, N. J., and Peterson, D. L.: A multi-century perspective of variability in the Pacific Decadal Oscillation: new insights from tree rings and coral, Geophys. Res. Lett., 29(D5), 4154, doi:10.1029/2002GL015824, 2002.

Geyh, M., Grosjean, M., Núñez, L., and Schotterer, U.: Radiocarbon reservoir effect and the timing of the late-glacial/early holocene humid phase in the Atacama Desert, Quaternary Res., 52, 143-153, 1999.

Grosjean, M., Cartajena, I., Geyh, M., and Nuñez, L.: From proxy data to paleoclimate interpretation: the mid-Holocene paradox of the Atacama Desert, northern Chile, Palaeogeogr. Palaeocl., 194, 247-258, 2003.

Grosjean, M., Geyh, M. A., Messerli, B., Schreier, H., and Veit, H.: A late-holocene $(<2600 \mathrm{BP})$ glacial advance in the south-central Andes (29 $\mathrm{S})$, northern Chile, Holocene, 8, 473-479, 1998.

Grosjean, M., Núñez, L., Cartajena, I., and Messerli, B.: Mid- 
Holocene climate and culture change in the Atacama Desert, Northern Chile, Quaternary Res., 48, 239-246, 1997.

Grosjean, M., Geyh, M. A., Messerli, B., and Schotterer, U.: Lateglacial and early Holocene lake sediments, ground-water formation and climate in the Atacama Altiplano $22-24^{\circ} \mathrm{S}$, J. Paleolimnol., 14, 241-252, 1995.

Grosjean, M.: Paleohydrology of the Laguna Lejía (north Chilean Altiplano) and climatic implications for late-glacial times, Palaeogeogr. Palaeocl., 109, 89-100, 1994.

Hansen, B. C. S., Rodbell, D. T., Seltzer, G. O., Leon, B., Young, K. R., and Abott, M.: Late-glacial and Holocene vegetational history from two sites in the western Cordillera of southwestern Ecuador, Palaeogeogr. Palaeocl., 194, 79-108, 2003.

Hansen, B. C. S. and Rodbell, D. T.: A Late Glacial/Holocene pollen record from the eastern Andes of northern Peru, Quaternary Res., 44, 216-227, 1995.

Hardy, D. R., Vuille, M., and Bradley, R. S.: Variability of snow accumulation an isotopic composition on Nevado Samja, Bolivia, J. Geophys. Res., 108(D22), 4693, doi:10.1029/2003JD003623, 2003.

Hastenrath, S.: Past glaciation in the tropics, Quaternary Sci. Rev., 28, 790-798, 2009.

Haug, G. H., Hughen, K. A., Sigman, D. M., Peterson, L. C., and Röhl, U.: Southward migration of the Intertropical Convergence Zone through the Holocene, Science, 293, 1304-1308, 2001.

Heine, K. and Heine, J. T.: Late Glacial fluctuations: Glacier retreat during Younger Dryas time, Arctic Alpine Res., 28, 496-501, 1996.

Henning, I. and Henning, D.: Die klimatologische Wasserbilanz der Kontinente, Münstersche Geographische Arbeiten, 19, Ferdinand Schöningh Verlag, Paderborn, 83 pp., 1984.

Hoffmann, G., Ramirez, E., Taupin, J. D., Francou, B., Ribstein, P., Delmas, R., Dürr, H., Gallaire, R., Simões, J., Schotterer, U., Stievenard, M., and Werner, M.: Coherent isotope history of Andean ice cores over the last century, Geophys. Res. Lett., 30, 1179, doi:10.1029/2002GL014870, 2003.

Jordan, E., Ungerechts, L., Cáceres, B., Peñafiel, A., and Francou, B.: Estimation by photogrammetry of the glacier recession on the Cotopaxi volcano (Ecuador) between 1956 and 1997, Hydrolog. Sci. J., 50, 959-961, 2005.

Koutavas, A., Lynch-Stieglitz, J., Marchitto Jr., T. M., and Sachs, J. P.: El Niño-like pattern in ice age tropical Pacific sea surface temperature, Science, 297, 226-230, 2002.

Kull, C. and Grosjean, M.: Albedo changes, Milankovitch forcing, and late Quaternary climate changes in the central Andes, Clim. Dyn., 14, 871-881, 1998.

Kull, C., Imhof, S., Grosjean, M., Zech, R., and Veit, H.: Late Pleistocene glaciation in the Central Andes: temperature versus humidity control - A case study from the eastern Bolivian Andes $\left(17^{\circ} \mathrm{S}\right)$ and regional synthesis, Global Planet. Change, 60, 148164, 2008

Latorre, C., Betancourt, J. L., Rylander, K. A., Quade, J., and Matthei, O.: A vegetation history from the arid prepuna of northern Chile $\left(22-23^{\circ} \mathrm{S}\right)$ over the last 13500 years, Palaeogeogr. Palaeocl., 194, 223-246, 2003.

Latorre, C.: Late Quaternary vegetation and climate history of a perennial river canyon in the Río Salado basin $\left(22^{\circ} \mathrm{S}\right)$ of Northern Chile, Quaternary Res., 65, 450-466, 2006.

Lea, D. W., Pak, D. K., and Spero, H. J.: Climate impact of late
Quaternary equatorial Pacific sea surface temperature variations, Science, 289, 1719-1724, 2000.

Liu, Z., Kutzbach, J., and Wu, L.: Modeling climate shift of El Nino variability in the Holocene, Geophys. Res. Lett., 27, 2265-2268, 2000.

Maldonado, A., Betancourt, J. L., Latorre, C., and Villagran, C.: Pollen analyses from a 50000-yr rodent midden series in the southern Atacama Desert (2530' S), J. Quaternary Sci., 20, 493 507, 2005.

Moy, C. M., Seitzer, G. O., Rodbell, D. T., and Anderson, D. M.: Variability of El Niño/Southern Oscillation activity at millennial timescales during the Holocene epoch, Nature, 420, 162-165, 2002.

Niemann, H. and Behling, H.: Late Quaternary vegetation, climate and fire dynamics inferred from the El Tiro record in the southeastern Ecuadorian Andes, J. Quaternary Sci., 23, 203-212, doi:10.1002/jqs.1134, 2008

Otto-Bliesner, B. L.: El Niño/La Niña and Sahel precipitation during the Holocene, Geophys. Res. Lett., 26, 87-90, 1999.

Paduano, G. M., Bush, M. B., Baker, P. A., Fritz, S. C., and Seltzer, G. O.: A vegetation and fire history of Lake Titicaca since the Last Glacial Maximum, Palaeogeogr. Palaeocl., 194, 259-279, 2003.

Porter, S. C.: Snowline depression in the tropics during the Last Glaciation, Quaternary Sci. Rev., 20, 1067-1091, 2001.

Poussart, P. F., Evans, M. N., and Schrag, D. P.: Resolving seasonality in tropical trees: multi-decade, high-resolution oxygen and carbon isotope records from Indonesia and Thailand, Earth Planet Sc. Lett., 218, 301-316, 2004.

Quinn, W. H. and Neal, V. T.: The historical record of El Niño events, in: Climate since AD 1500, edited by: Bradley, R. S. and Jones, P. D., Routledge, London and New York, 623-648, 1992.

Rech, J. A., Quade, J., and Betancourt, J. L.: Late Quaternary paleohydrology of the ventral Atacama Desert (lat $22^{\circ}-24^{\circ} \mathrm{S}$ ), Chile, GSA Bulletin, 114, 334-348, 2002.

Rein, B., Lückge, A., and Sirocko, F.: A major Holocene ENSO anomaly during the Medieval period, Geophys. Res. Lett., 31, L17211, doi:10.1029/2004GL020161, 2004.

Rodbell, D. T., Seltzer, G. O., Anderson, D. M., Abbott, M. B., Enfield, D. B., and Newman, J. H.: An 15000-year record of El Niño-driven alluviation in southwestern Ecuador, Science, 283 516-520, 1999.

Rodriguez, R., Mabres, A., Luckman, B., Evans, M., Masiokas, M., and Ektvedt, T. M.: "El Niño" events recorded in dry-forest species of the lowlands of northwest Peru, Dendrochronologia, 22, 181-186, 2005.

Sandweiss, D. H., Richardson III, J. B., Reitz, E. J., Rollins, H. B., and Maasch, K. A.: Geoarchaeological evidence from Peru for a 5000 years B.P. onset of El Niño, Science, 273, 1531-1533, 1996.

Seltzer, G. O., Rodbell, D. T., Baker, P. A., Fritz, S. C., Tapia, P. M., Rowe, H. D., and Dunbar, R. B.: Early warming of tropical South America at the last glacial-interglacial transition, Science, 296, 1685-1986, 2002.

Servant, M. and Servant-Vildary, S.: Holocene precipitation and atmospheric changes inferred from river paleowetlands in the Bolivian Andes, Palaeogeogr. Palaeocl., 194, 187-206, 2003.

Stahle, D. W., D’Arrigo, R. D., Krusic, P. J., Cleaveland, M. K., Cook, E. R., Allan, R. J., Cole, J., Dunbar, R. B., Therrell, M. 
D., Gay, D. A., Moore, M. D., Stokes, M. A., Burns, B. T., Villanueva-Diaz, J., and Thompson, L. G.: Experimental dendroclimatic reconstruction of the southern oscillation, B. Am. Meteorol. Soc., 79, 2137-2152, 1998

Stokes, M. A. and Smiley, T. L.: An Introduction to Tree-Ring Dating, The University of Chicago Press: Chicago, London, p. 73, 1968.

Stuut, J.-B. W., and Lamy, F.: Climate variability at the southern boundaries of the Namib (southwestern Africa) and Atacama (northern Chile) coastal deserts during the last 120000 yr., Quaternary Res., 62, 301-309, 2004.

Sylvestre, F., Servant, M., Servant-Vildary, S., Causse, C., Fournier, M., and Ybert, J.-P.: Lake-level chronology on the southern Bolivian Altiplano $\left(18^{\circ}-23^{\circ} \mathrm{S}\right)$ during late-glacial time and the early Holocene, Quaternary Res., 51, 54-66, 1999.

Thompson, L. G., Mosley-Thompson, E., Davis, M. E., Lin, P. N., Henderson, K., and Mashiotta, T. A.: Tropical glaciers and ice core evidence of climate change on annual to millennial time scales, Climatic Change, 59, 137-155, 2003.

Thompson, L. G., Mosley-Thompson, E., and Henderson, K. A.: Ice core palaeoclimate records in tropical South America since the last glacial maximum, J. Quaternary Sci., 15, 377-394, 2000.

Trenberth, K. E. and Caron, J. M.: The Southern Oscillation revisited: sea level pressures, surface temperatures, and precipitation, J. Climate, 13, 4358-4365, 2000.

Tudhope, A. W., Chilcott, C. P., McCulloch, M. T., Cook, E., Chappell, J., Ellam, R. M., Lea, D. W., Lough, J. M., and Shimmield, G. B.: Variability in the El Niño-Southern Oscillation through a glacial-interglacial cycle, Science, 291, 1511-1517, 2001.

Valero-Garcés, B. L., Grosejean, M., Schwalb, A., Geyh, M., Messerli, B., and Kelts, K.: Limnogeology of Laguna Miscanti: evidence for mid to late Holocene moisture changes in the Atacama Altiplano (Northern Chile), J. Paleolimnol., 16, 1-21, 1996. van der Hammen, T.: The Pleistocene changes of vegetation and climate in tropical South America, J. Biogeogr., 1, 3-26, 1974.

van Geel, B., Heusser, C. J., Renssen, H., and Schuurmans C. J. E.: Climatic change in Chile at around $2700 \mathrm{BP}$ and global evidence for solar forcing: a hypothesis, Holocene, 10, 659-664, 2000.

Vetter, R. E.: Growth periodicities and age of Amazonian tree species. Methods for their determination, in: Dendrocronología in América Latina, edited by: Roig, F. A., EDIUNC, Mendoza, 133-155, 2000.

Villalba, R.: Tree-ring and glacial evidence for the medieval Warm Epoch and the Little Ice Age in southern South America, Climatic Change, 26, 183-197, 1994.

Volland-Voigt, F., Bräuning, A., and Ganzhi, O.: High-resolution dendrometer measurements in a tropical mountain rainforest and a dry forest in South Ecuador, TRACE - Tree Rings in Archaeology, Climatology and Ecology, 7, 85-88, 2009.

von Schnakenburg, P., Bräuning, A., and Helle, G.: Detecting annual growth rhythms from high-frequency densitometry and carbon isotopes in tropical mountain rain forest trees in southern Ecuador. TRACE - Tree Rings in Archaeology, Climatology and Ecology, 6, 96-99, 2008.

Wells, L.: Holocene history of the El Niño phenomenon as recorded in flood sediments of northern coastal Peru, Geology, 18, 1134 1137, 1990.

Wigley, T., Briffa, K. R., and Jones, P. D.: On the average value of correlated time series, with applications in dendroclimatology and hydrometeorology, J. Appl. Meteorol., 23, 201-213, 1984.

Worbes, M.: One hundred years of tree-ring research in the tropics: a brief history and an outlook to future challenges, Dendrochronologia, 20, 217-231, 2002.

Zech, R., May, J.-H., Kull, C., Ilgner, J., Kubik, P. W., and Veit, H.: Timing of the Late Quaternary glaciation in the Andes from 15 to $40^{\circ}$ S, J. Quaternary Sci., 23, 635-674, 2008. 